\title{
Genetic Variability and Path Analysis Studies in Hybrid Maize (Zea mays L.)
}

\author{
Mohammad Quamrul Islam Matin 1*, Md. Shalim Uddin', Md. Motiar Rohman', \\ Mohammad Amiruzzaman', Abul Kalam Azad1, Bhagya Rani Banik² \\ ${ }^{1}$ Bangladesh Agricultural Research Institute (BARI), Gazipur, Bangladesh \\ ${ }^{2}$ Bangladesh Agricultural Research Council (BARC), Dhaka, Bangladesh \\ Email: *quamrul_islam76@yahoo.com, shalimuddin@yahoo.com, motiar_1@yahoo.com, csopbreeding@yahoo.com, \\ dg.bari@bari.gov.bd,ec-barc@barc.gov.bd
}

How to cite this paper: Matin, M.Q.I., Uddin, Md.S., Rohman, Md.M., Amiruzzaman, M., Azad, A.K. and Banik B.R. (2017) Genetic Variability and Path Analysis Studies in Hybrid Maize (Zea mays L.). American Journal of Plant Sciences, 8, 3101-3109.

https://doi.org/10.4236/ajps.2017.812209

Received: September 18, 2017

Accepted: November 17, 2017

Published: November 22, 2017

Copyright $\odot 2017$ by authors and Scientific Research Publishing Inc. This work is licensed under the Creative Commons Attribution International License (CC BY 4.0).

http://creativecommons.org/licenses/by/4.0/

(c) (i) Open Access

\begin{abstract}
The present study was carried out to access correlation coefficient, path analysis and genetic variability among twenty one locally developed maize hybrids for ten characters. Positive and significant genotypic, phenotypic correlation coefficient were recorded for yield with anthesis silking interval $\left(r_{g}=1.00^{* *}, r_{p}\right.$ $\left.=0.96^{\star *}\right)$, cob diameter $\left(r_{g}=0.99^{* *}\right.$ and $\left.r_{p}=0.95^{\star *}\right)$ and ear height $\left(r_{g}=0.98^{\star *}\right.$ and $r_{p}=0.94^{\star *}$ ). But days to $50 \%$ tasseling had moderate but significant positive correlation at both phenotypic and genotypic level. High genotypic coefficient of variation (GCV) was obtained from thousand seed weight, days to $50 \%$ silking, cob diameter and anthesis silking interval. The highest phenotypic coefficient of variation (PCV) was observed in thousand seed weight followed by days to $50 \%$ silking and cob diameter. The highest heritability $\mathrm{Hb}$ ) was observed for cob diameter (95.25) followed by days to $50 \%$ silking (94.15), days to maturity (93.85) and ear height (93.06). The characters with high GCV and higher values of heritability indicated high potential for selection. Anthesis silking interval (0.79) had the highest positive direct effect on yield followed by cob diameter (0.31), cob length (0.31) and plant height (0.04) indicating the effectiveness of direct selection. While some other characters such as days to $50 \%$ tasseling $(-0.12)$, days to $50 \%$ silking $(-1.78)$, ear height $(-1.16)$, days to maturity $(-0.64)$ exhibited indirect negative effect on yield indicating the effectiveness of indirect selection.
\end{abstract}

\section{Keywords}

Genetic Variability, Path Co-Efficient, Hybrid Maize 


\section{Introduction}

Maize (Zea mays L.; $2 \mathrm{n}=20$ ) is a monoecious; $\mathrm{C} 4$ plant belongs to the tribe Maydeae of the family Poaceae. It is a tall, robust, annual, usually with a single dominant stem, although there may be few tillers in some genotypes and environments.

The suitability of maize to diverse environments is unmatched by any other crop. It is grown from $58^{\circ} \mathrm{N}$ to $40^{\circ} \mathrm{S}$, from below sea level to altitudes higher than $3000 \mathrm{~m}$, and in areas with $250 \mathrm{~mm}$ to more than $5000 \mathrm{~mm}$ of rainfall per year [1] and [2]. Most of the crop is, however, grown in the warmer parts of temperate regions and in humid subtropical climate, and the greatest production is in areas having the warmest month isotherms from $21^{\circ} \mathrm{C}$ to $27^{\circ} \mathrm{C}$ and a frost free season of 120 to 180 day duration.

Maize plays a significant role in human and livestock nutrition worldwide [3]. It is the world's most widely grown cereal and is the primary staple food in many developing countries [4]. It is a versatile crop with wider genetic variability and able to grow successfully throughout the world covering tropical, subtropical and temperate agro-climatic conditions.

Presently maize is cultivated in 165 countries on 184 million hectares (ha), and has a production of 1,016 million tons $(t)$ and productivity of $5.52 \mathrm{t} / \mathrm{ha}$ globally. In terms of production, India, with 9.4 million ha, ranks fourth globally, after the USA States (35.5 million ha), China (35.3 million ha) and Brazil (15.4 million ha) [5].

Maize could be good source of nutrition for under nourished and malnourished population in Bangladesh. It is now widely used in the poultry farms, fisheries and animal feeding, as well as the people consume roasted and fried maize in Bangladesh. The maize cob is nutritionally rich at both green and mature stage. Yellow maize kernel contains carotene which is a precursor of Vitamin A. It contains more amount of fat than rice and wheat [6].

Maize in Bangladesh is becoming an important crop in the rice based cropping system. It is the third important cereal crop after rice and wheat. In recent year's maize is gaining popularity among the farmers mainly due to high yield, more economic return and versatile uses it is the highest yielding grain crop having multiple uses. The need for demand of maize is increasing gradually. The area and production of maize is increasing day by day in Bangladesh and it continues to expand rapidly at an average rate of $20 \%$ year $^{-1}$ [7].

According to [8] the production in Bangladesh was 11.37, 13.70, 15.52, 19.54, $21.78,25.16,27.59$ lac metric ton in the year of 2008-2009, 2009-2010, 2010-2011, 2011-2012, 2012-2013, 2013-2014, 2015-2016 with an area occupying $1.74,2.02,2,27,2.83,3.12,3.64$ and 3.95 lac ha. The yield was $6.53,6.78,6.84$, $6.90,6.98,6.91$ and $6.97 \mathrm{t} / \mathrm{ha}$ respectively.

The efficiency of breeding programme depends mainly on the direction and magnitude of association between yield and its components and also the relative importance of each factor involved in contributing to grain yield [9]. 
The path analysis provides the effective measures of direct and indirect causes of association and depicts the relative importance of each factor involved in contributing to the final product [9]. For efficient selection of grain yield, like the most important economic trait, in regard to it on the great influence the environmental factor, has complex mode of inheritance and low heritability, is necessary to know relation between grain yield and morphological traits which are influencing on the grain yield [10].

Keeping in mind the experiment was conducted with following objectives

i) tosubmit correlative relationship between grain yield and other morphological traits and;

ii) also founding direct and indirect effects of those traits on yield.

\section{Materials and Methods}

The experiment was carried out at research field of Plant Breeding Division, Bangladesh Agricultural Research Institute (BARI), Gazipur, Bangladesh in the rabi season of 2014-15. Twenty one hybrids and three check varieties were evaluated in this study. The experiment was laid out in Randomized Complete Block Design with 3 replications. The twenty one hybrids were developed from seven parental lines using diallel mating without the reciprocals during the rabiseason in 2012-2013. The source materials were from both BARI and CIMMYT such as P1 = BIL20, P2 = BML36, P3 = BIL77, P4 = BIL106, P5 = CLQRCY44, P6 $=$ BIL79 and P7 $=$ BIL 31.The parents were selected based on their combining ability performance such as general combining ability (GCA) and specific combining ability (SCA). The hybrids developed through diallel mating design were as follows $\mathrm{P} 1 \times \mathrm{P} 2, \mathrm{P} 1 \times \mathrm{P} 3, \mathrm{P} 1 \times \mathrm{P} 4, \mathrm{P} 1 \times \mathrm{P} 5, \mathrm{P} 1 \times \mathrm{P} 6, \mathrm{P} 1 \times \mathrm{P} 7, \mathrm{P} 2 \times \mathrm{P} 3, \mathrm{P} 2 \times$ $\mathrm{P} 4, \mathrm{P} 2 \times \mathrm{P} 5, \mathrm{P} 2 \times \mathrm{P} 6, \mathrm{P} 2 \times \mathrm{P} 7, \mathrm{P} 3 \times \mathrm{P} 4, \mathrm{P} 3 \times \mathrm{P} 5, \mathrm{P} 3 \times \mathrm{P} 6, \mathrm{P} 3 \times \mathrm{P} 7, \mathrm{P} 4 \times \mathrm{P} 5, \mathrm{P} 4 \times$ $\mathrm{P} 6, \mathrm{P} 4 \times \mathrm{P} 7, \mathrm{P} 5 \times \mathrm{P} 6, \mathrm{P} 5 \times \mathrm{P} 7, \mathrm{P} 6 \times \mathrm{P} 7$.

Seeds of each entry were sown in 2 rows, 4 m long plots with $60 \mathrm{~cm}$ and $20 \mathrm{~cm}$ spacing between rows and hills, respectively. Seeds were sown at Gazipur on 24 November, 2014. One healthy seedling per hill was kept after thinning. Fertilizers were applied at the rate of 250,55, 110, 40, 5 and $1.5 \mathrm{~kg} / \mathrm{ha}$ of $\mathrm{N}, \mathrm{P}_{2} \mathrm{O}_{5}, \mathrm{~K}_{2} \mathrm{O}$, $\mathrm{S}, \mathrm{Zn}$ and $\mathrm{B}$ respectively. Standard agronomic practices were followed [11] and plant protection measures were taken as required. Two border rows at both end of each replication were used for minimize the border effect. Data on days to $50 \%$ tasseling (DT), days to 50\% silking (DS), and anthesis silking interval (ASI), plant height( $\mathrm{PH}$ ),ear height (EH), days to maturity (DM), cob length (CL), cob diameter (CD), thousand seed weight (TSW) and yield ( $t / h a)$ were recorded. All the plants in two rows were considered for plot yield and converted to $t / h a$.

Genotypic and phenotypic variance, heritability and genetic advance were measured according to the formula proposed by [12] [13] and [14]. Genotypic and phenotypic co-efficient of variation calculated following [15]. Path co-efficient analysis estimated by Dewey and $\mathrm{Lu}$ [16]. All the data were processed and analyzed according to [17]. 


\section{Results and Discussion}

Mean sum of squares from pooled analysis revealed significant effects for yield. All the characters showed significant treatment effects indicating that all the twenty one hybrids were differed for those characters indicating the sufficient variability among them (Table 1 ).

The highest $\sigma^{2} \mathrm{~g}(108560.39)$ and $\sigma^{2} \mathrm{p}(110976.23)$ variance were found for TSW (Table 2). The lowest magnitude $\sigma^{2} g$ (7.03), $\sigma^{2} \mathrm{p}(8.39)$ variance were observed in DT. High genotypic coefficient of variation (GCV) were obtained from TSW (103.75), DS (97.66), CD (92.24) and ASI (87.99). The characters with high GCV indicated high potential for selection. [18] selected some traits with high GCV in $B$ juncea. The highest phenotypic coefficient of variation (PCV) were observed in TSW (107.16) followed by DS (100.65), CD (94.51) and the lowest in

Table 1. Pooled analysis of variance using ten characters in maize.

\begin{tabular}{ccccccc}
\hline S.V & d.f & DT & DS & ASI & PH $(\mathrm{cm})$ & EH $(\mathrm{cm})$ \\
\hline Replication & 2 & 1.06 & 186.333 & 744.73 & 451.67 & 77.9 \\
Treatment & 20 & $22.46^{* *}$ & $6,636.17^{* *}$ & $28,689.07^{* *}$ & $5,019.76^{* *}$ & $2,686.62^{* *}$ \\
Error & 40 & 1.36 & 134.65 & 741.58 & 191.16 & 65.70 \\
\hline & & & & & & \\
\hline S.V & d.f & DM & CL $(\mathrm{cm})$ & $\mathrm{CD}(\mathrm{cm})$ & TSW $(\mathrm{gm})$ & Yld.(t/ha) \\
\hline Replication & 2 & 221.552 & 5.68 & 718.317 & $5,223.866$ & 1.414 \\
Treatment & 20 & $10,883.09 * *$ & $452.54^{* *}$ & $103,353.54^{* *}$ & $110,976.24^{* *}$ & $5,305.42^{* *}$ \\
Error & 40 & 232.55 & 12.05 & $1,687.79$ & $2,415.84$ & 267.97 \\
\hline
\end{tabular}

* indicates significant at $5 \%$ level and ${ }^{* *}$ indicates significant at $1 \%$ level. Days to $50 \%$ tasseling (DT), days to $50 \%$ silking (DS), Anthesissilking interval (ASI), plant height (PH), ear height (EH), days to maturity (DM), cob length (CL), cob diameter (CD), thousand seed weight (TSW) and yld (yield t/ha).

Table 2. Estimates of genetic parameters for ten characters in maize.

\begin{tabular}{cccccccc}
\hline Characters & $\sigma^{2} \mathrm{~g}$ & $\sigma^{2} \mathrm{p}$ & GCV $(\%)$ & PCV $(\%)$ & Hb $(\%)$ & GA & GAPM \\
\hline DT & 7.03 & 8.39 & 2.762 & 3.01 & 83.76 & 5.00 & 5.20 \\
DS & 2167.17 & 2301.82 & 97.66 & 100.65 & 94.15 & 93.05 & 195.21 \\
ASI & 9315.83 & 10057.41 & 87.99 & 91.42 & 92.62 & 191.35 & 174.45 \\
PH & 1609.53 & 1800.69 & 29.19 & 30.87 & 89.38 & 78.13 & 56.85 \\
EH & 873.64 & 939.34 & 24.20 & 25.10 & 93.00 & 58.72 & 48.08 \\
DM & 3550.36 & 3782.91 & 70.26 & 72.53 & 93.85 & 118.90 & 140.22 \\
CL & 146.83 & 158.88 & 78.82 & 81.99 & 92.41 & 23.99 & 156.10 \\
CD & 33888.58 & 35576.37 & 92.248 & 94.518 & 95.25 & 370.11 & 185.46 \\
TSW & 108560.39 & 110976.23 & 103.756 & 107.163 & 93.74 & 379.41 & 206.94 \\
Yld. & 1679.15 & 1947.12 & 78.225 & 84.236 & 86.23 & 78.39 & 149.64
\end{tabular}

$\sigma^{2} \mathrm{~g}, \sigma^{2} \mathrm{p}$ : Genotypic variance and phenotypic variance, GCV, PCV: Genotypic and phenotypic coefficient of variation, Hb: Heritability, GA: Genetic advance, GAPM: Genetic advance as percentage of mean. 
DT (3.01). The difference between GCV and PCV of yield indicated that the character had some environmental influence. All the traits showed high heritability indicating lower influence of environment which also observed in the study of [19]. The highest $\mathrm{Hb}$ was observed for $\mathrm{CD}$ (95.25) followed by DS (94.15), DM (93.852) and EH (93.00) but the lowest Hb identified for DT (83.76) followed by the yield (86.23). The higher values of heritability of aforementioned traits were indicative for selection, supported by [20] and [21].The highest GA was reported in TSW (379.41) followed by CD (370.11), ASI (191.35) and DM (118.90) resulting to the highest GAPM in TSW (206.94), DS (195.21), CD (185.46), respectively. [22] reported that the characters which have high $\mathrm{Hb}$ value along with high GA was due to additive gene effects. Again [19] showed that high heritability accompanied with low genetic advance revealed nonadditivegane action.

\subsection{Genotypic and Phenotypic Correlation Coefficients with Yield}

The genotypic (upper diagonal) and phenotypic (lower diagonal) correlation coefficients for all nine traits were presented (Table 3). The yield had the highest positive genotypic $\left(\mathrm{r}_{\mathrm{g}}\right)$ and phenotypic $\left(\mathrm{r}_{\mathrm{p}}\right)$ correlation coefficient with ASI $\left(\mathrm{r}_{\mathrm{g}}=\right.$ $\left.1.00^{\star *}, r_{p}=0.96^{\star *}\right), \mathrm{CD}\left(r_{g}=0.99^{\star *}\right.$ and $\left.r_{p}=0.95^{\star *}\right)$ and $\mathrm{EH}\left(r_{g}=0.98^{\star *}\right.$ and $r_{p}=$ $\left.0.94^{* *}\right)$. Positive correlation coefficient with yield was recorded with $\mathrm{CD}$ and $\mathrm{EH}$ in an study of [23] [24] and [25]. DT had moderate significant and positive correlation with yield $\left(r_{\mathrm{g}}=0.65^{\star *}, \mathrm{r}_{\mathrm{p}}=0.62^{\star *}\right)$, at both genotypic and phenotypic levels. In most of the case, genotypic correlation was higher than phenotypic correlation that indicated the association was due to genetic reason (strong coupling phase) [26].

Table 3. Genotypic (upper diagonal) and phenotypic (lower diagonal) correlation with yield.

\begin{tabular}{ccccccccccc}
\hline & DT & DS & ASI & PH & EH & DM & CL & CD & TSW & YLD \\
\hline DT & & $-0.68^{* *}$ & $0.70^{* *}$ & $-0.78^{* *}$ & $0.61^{* *}$ & $-0.69^{* *}$ & $-0.75^{* *}$ & $0.67^{* *}$ & $-0.72^{* *}$ & $0.65^{* *}$ \\
DS & $-0.64^{* *}$ & & $-0.99^{* *}$ & $0.94^{* *}$ & $-0.98^{* *}$ & $1.00^{* *}$ & $0.98^{* *}$ & $-0.99^{* *}$ & $0.99^{* *}$ & $-1.00^{* *}$ \\
ASI & $0.66^{* *}$ & $-0.99^{* *}$ & & $-0.94^{* *}$ & $0.97^{* *}$ & $-0.99^{* *}$ & $-0.99^{* *}$ & $0.98^{* *}$ & $-0.99^{* *}$ & $1.00^{* *}$ \\
PH & $-0.73^{* *}$ & $0.92^{* *}$ & $-0.92^{* *}$ & & $-0.88^{* *}$ & $0.95^{* *}$ & $0.98^{* *}$ & $-0.95^{* *}$ & $0.98^{* *}$ & $-0.94^{* *}$ \\
EH & $0.59^{* *}$ & $-0.98^{* *}$ & $0.97^{* *}$ & $-0.85^{* *}$ & & $-0.98^{* *}$ & $-0.94^{* *}$ & $0.97^{* *}$ & $-0.95^{* *}$ & $0.98^{* *}$ \\
DM & $-0.66^{* *}$ & $0.99^{* *}$ & $-0.99^{* *}$ & $0.93^{* *}$ & $-0.97^{* *}$ & & $0.99^{* *}$ & $-0.99^{* *}$ & $0.99^{* *}$ & $-1.00^{* *}$ \\
CL & $-0.70^{* *}$ & $0.98^{* *}$ & $-0.98^{* *}$ & $0.95^{* *}$ & $-0.94^{* *}$ & $0.98^{* *}$ & & $-0.98^{* *}$ & $1.00^{* *}$ & $-0.99^{* *}$ \\
CD & $0.63^{* *}$ & $-0.97^{* *}$ & $0.97^{* *}$ & $-0.92^{* *}$ & $0.96^{* *}$ & $-0.98^{* *}$ & $-0.97^{* *}$ & & $-0.98^{* *}$ & $0.99^{* *}$ \\
TSW & $-0.68^{* *}$ & $0.98^{* *}$ & $-0.98^{* *}$ & $0.94^{* *}$ & $-0.95^{* *}$ & $0.99^{* *}$ & $0.99^{* *}$ & $-0.97^{* *}$ & & $-0.99^{* *}$ \\
YLD & $0.60^{* *}$ & $-0.96^{* *}$ & $0.96^{* *}$ & $-0.89^{* *}$ & $0.94^{* *}$ & $-0.96^{* *}$ & $-0.95^{* *}$ & $0.95^{* *}$ & $-0.95^{* *}$ & \\
\hline
\end{tabular}

* indicates significant at $5 \%$ level and ${ }^{* *}$ indicates significant at $1 \%$ level. Days to $50 \%$ tasseling (DT), days to $50 \%$ silking (DS), Anthesissilking interval (ASI), plant height(PH), ear height (EH), days to maturity (DM), cob length (CL), cob diameter (CD), thousand seed weight (TSW) and yld. (yieldt/ha). 
Negative significant correlation was found in DM with yield $\left(\mathrm{r}_{\mathrm{g}}=-1.00^{* *}\right.$ and $\left.r_{p}=-0.96^{\star *}\right)$, DS $\left(r_{g}=-1.00^{\star *}\right.$ and $\left.r_{p}=-0.96^{\star *}\right)$ and CL $\left(r_{g}=-0.99^{\star *}\right.$ and $r_{p}=$ $\left.-0.95^{\star *}\right)$, at both genotypic and phenotypic levels. Similar findings were also recorded in the observation of [27].

\subsection{Path Coefficient Analysis}

Association of character determined by correlation co-efficient may not provide an exact picture of the relative importance of direct and indirect influence of each of yield components of yield. In order to find out a clear picture of the inter-relationship between yield and other yield attributes, direct and indirect effects were worked out using path analysis both ant genotypic and phenotypic level which also measured relative importance of each components. Yield was considered as a resultant variable other characters estimated as causal or independent variable [28].

Yield being a complex entity was influenced by several components and selection based primarily on correlations without considering cause and effect relationship can be misleading [29]. So, the genotypic correlation coefficients were partitioned into direct and indirect effects through path coefficient analysis (Table 4) to get a clear picture under this complex situation. ASI had the highest positive direct effect (0.79) on yield followed by CD (0.31), CL(0.31) and PH (0.04) which was supported by [30] and [31]. ASI, CD showed the maximum positive correlation with yield.

Direct negative effect on yield was shown by DS (-1.78), EH (-1.16), DM $(-0.64)$ and DT $(-0.12)$ which were in agreement with [9] and [19]. Direct negative effect indicating the effectiveness of indirect selection. But EH, DT showed positive correlation with yield, while DS and DM exhibited negative correlation.

The residual effect was 0.014 indicating there were also some other characters which although not studied but influenced the seed yield.

Table 4. Direct (bold) and indirect effect of different traits at genotypic level onyield.

\begin{tabular}{ccccccccccc}
\hline Characters & DT & DS & ASI & PH & EH & DM & CL & CD & TSW & $\mathrm{r}_{\mathrm{g}}$ with Yld. \\
\hline DT & -0.12 & 1.22 & 0.56 & -0.03 & -0.71 & 0.44 & -0.23 & 0.21 & -0.69 & $0.65^{* *}$ \\
DS & 0.08 & -1.78 & -0.79 & 0.04 & 1.15 & -0.64 & 0.30 & -0.31 & 0.94 & $-1.00^{* *}$ \\
ASI & -0.08 & 1.78 & 0.79 & -0.04 & -1.14 & 0.64 & -0.31 & 0.31 & -0.95 & $1.00^{* *}$ \\
PH & 0.09 & -1.68 & -0.75 & 0.04 & 1.03 & -0.61 & 0.30 & -0.30 & 0.93 & $-0.94^{* *}$ \\
EH & -0.07 & 1.76 & 0.78 & -0.04 & -1.16 & 0.63 & -0.29 & 0.30 & -0.91 & $0.98^{* *}$ \\
DM & 0.08 & -1.78 & -0.79 & 0.04 & 1.14 & -0.64 & 0.31 & -0.31 & 0.95 & $-1.00^{* *}$ \\
CL & 0.09 & -1.76 & -0.79 & 0.04 & 1.10 & -0.63 & 0.31 & -0.31 & 0.95 & $-0.99^{* *}$ \\
CD & -0.08 & 1.77 & 0.79 & -0.04 & -1.13 & 0.63 & -0.30 & $\mathbf{0 . 3 1}$ & -0.94 & $0.99^{* *}$ \\
TSW & 0.08 & -1.77 & -0.79 & 0.04 & 1.11 & -0.63 & 0.31 & -0.31 & $\mathbf{0 . 9 5}$ & $-0.99^{* *}$ \\
\hline
\end{tabular}

Days to $50 \%$ tasseling (DT), days to $50 \%$ silking (DS), Anthesissilking interval (ASI), plant height (PH), ear height (EH), days to maturity (DM), cob length (CL), cob diameter (CD), thousand seed weight (TSW) and yld. (yield $t / h a)$. Residual effect $\left(R^{2}\right)=0.014$ 


\section{Conclusion}

High genotypic coefficient of variation (GCV) were obtained from thousand seed weight (TSW), days to 50\% silking (DS), cob diameter (CD) and anthesis silking interval (ASI). The highest $\mathrm{Hb}$ was observed for $\mathrm{CD}$ followed by days to $50 \%$ silking (DS), days to maturity (DM) and ear height (EH). The characters with high GCV and higher values of heritability indicated high potential for selection. Positive and significant genotypic, phenotypic correlation coefficient were recorded for yield with anthesis silking interval (ASI), cob diameter (CD) and ear height (EH). But days to $50 \%$ tasseling (DT) had moderate but significant positive correlation at both phenotypic and genotypic level. ASI had the highest positive direct effect on yield followed by cob diameter (CD), cob length (CL) and plant height $(\mathrm{PH})$ indicating the effectiveness of direct selection. On the other hand, some characters such as days to $50 \%$ silking (DS), ear height (EH), days to maturity (DM) and days to $50 \%$ tasseling (DT) showed indirect negative effect on yield. Those traits could be used as indirect selection.

\section{Conflicts of Interests}

There was no conflict of interests.

\section{References}

[1] Shaw, R.H. (1988) Climatic Requirement, In: Sprague, G.F. and Dudley, J.W., Eds., Corn and Corn Improvement, Am. Soc. Agron., Madison, Wisconsin, 609-638.

[2] Dowswell, C.R., Paliwal, R.L. and Cantrell, R.P. (1996) Maize in the Third World. West View Press, Boulder.

[3] Annonymous (2004) Annual Report 1989, beyond Subsistence. New Options for Asian Farmers, CIMMYT, Mexico. 145-148.

[4] Morris, M.L., Risopoulos, J. and Beck. D. (1999) Genetic Change in Farmer-Recycled Maize Seed; a Review of the Evidence. CIMMYT Economic Working Paper No. 99-07. Mexico, D.F., CIMMYT. 1.

[5] Yadav, O.P., Karjagi, G.C., Kumar, B., Jat, S.L., Chawla, J.S., Kaul, J., Huda, K.S., Kumar, P., Yadav, P. and Dhillon, B.S. (2014) Maize Improvement in India. 12th Asian Maize Conference and Expert Consultation on "Maize for Food, Feed, Nutrition and Environmental Security”, Bangkok, 30 October-1 November 2014.

[6] Gopalan, C., Rama, B.V., Sastri and Balasubramanian, S.C. (1981) Nutritive Value of Indian Foods. National Institute of Nutrition, ICMR, Hyderabad, 57-63.

[7] CIMMYT (International Maize and Wheat Improvement Center) (2008) Achievements of the Bangladesh-CIMMYT Partnership for Agricultural Research and Development. CIMMYT-Bangladesh, Banani, Dhaka, 1-9.

[8] DAE (Department of Agricultural Extension) (2017) Ministry of Agriculture, Khamarbari, Farmgate, Dhaka.

[9] Jakhar, D.S., Singh, R. and Kumar, A. (2017) Studies on Path Coefficient Analysis in Maize (Zea mays L.) for Grain Yield and Its Attributes. International Journal of Current Microbiology and Applied Sciences, 6, 2851-2856. https://doi.org/10.20546/ijcmas.2017.604.327

[10] Sreckov, Z., Bocanski, J., Nastasic, A., Dalovic, I. and Vukosavijev, M. (2010) Cor- 
relation and Path Coefficient Analysis of Morphological Traits of Maize (Zea mays L.). Research Journal of Agricultural Science, 42.

[11] Quayyum, M.A. (1993) Bhuttar Chash Paddhati (in Bengali). In: Chowdhury, M.K. and Islam, M.A., Eds., Bhuttar Utpadan O Babohar, Bangladesh Agricultural Research Institute, Gazipur, 43-48.

[12] Johnson, H.W., Robinson, H.F. and Comstock, R.E. (1955) Estimates of Genetic and Environmental Variability in Soyabeans. Agronomy Journal, 47, 14-18.

[13] Singh, R.K. and Chaudhary, B.D. (1985) Biometrical Methods in Quantitative Genetic Analysis. Kalyani Publishers, New Delhi, 56.

[14] Allard, R.W. (1960) Principles of Plant Breeding. John Willey and Sons Inc., New York, 36

[15] Burton, G.W. (1952) Quantitative Inheritance in Grass Pea. Proc. 6th Grassl. Cong. Vol. 1, 277-283.

[16] Dewey, D.R. and Lu, K.H. (1959) A Correlation, Path Coefficient Analysis of Components of Crested Wheat Grass Seed Production. Agronomy Journal, 51, 515-518. https://doi.org/10.2134/agronj1959.00021962005100090002x

[17] Sheoran, O.P., Tonk, D.S., Kaushik, L.S., Hasija, R.C. and Pannu, R.S. (1998) Statistical Software Package for Agricultural Research Workers. Department of Mathmetics Statistics, CCS HAU, Hisar, 139-143.

[18] Alam, M.S., Das, M.K. and Khair, A.B.M.A. (1988) Genetic Variation, Correlation and Path Analysis of B. juncea (Lo). Bangladesh Journal of Plant Breeding and Genetics, 1, 116-122.

[19] Begum, S., Ahmed, A., Omy, S.H., Rohman, M.M. and Amiruzzaman, M. (2016) Genetic Variability, Character Association and Path Analysis in Maize (Zea mays L.). Bangladesh Journal of Agricultural Research, 41, 173-182. https://doi.org/10.3329/bjar.v41i1.27682

[20] Ali, Q., Elahi, M., Ahsan, M., Tahir, M.H.N and Basra, S.M.A. (2012) Genetic Evaluation of Maize (Zea mays L.) Associations for Growth Related Seedlings Traits. IJA VMS, 6, 164-172. https://doi.org/10.5455/ijavms.20110608051727

[21] Moulin, S., Baret, F, Bruguier, N. and Bataille (2009) Assessing the Vertical Distribution of Leaf Chlorophyll Content in a Maize Crop. INRA Unite Climate, Soil, Environment (CSE), 7803-7929.

[22] Panse, V.G. (1957) Genetics or Quantitative Characters in Relation to Plant Breeding. Indian Journal of Genetics and Plant Breeding, 17, 318-346.

[23] Nataraj, V., Sathi, J.P. and Agarwal, V. (2014) Correlation and Path Analysis in Certain Inbred Genoptypesof Maize (Zea mays L.) at Varanasi. International Journal of Innovative Research in Science Engineering and Technology, 14-17.

[24] Ojo, D.K., Omikunle, O.A., Oduwoye, O.A., Ajala, M.O. and Ogunbayo, S.A. (2006) Heritability, Character Correlation and Path Coefficient among Six Inbred Lines of Maize. World Journal of Agricultural Sciences, 3, 352-358.

[25] Batool, Z., Danial, K., Alireza, P.A. and Forhad, S. (2012) Correlation and Path Coefficient Analysis for Determining Interrelationship among Grain Yield and Related Characters in Corn Hybrids (Zea mays L.). International Journal of Agriculture and Crop Sciences, 4, 1519-1522.

[26] Sharma, J.R. (1988) Statistical and Biometrical Techniques in Plant Breeding. New Age International (Pvt.) Ltd., New Delhi, 35.

[27] Sadek, S.E., Ahmed, M.A. and Abd El-Ghaney, H.M. (2006) Correlation and Path 
Coefficient Analysis in Five Parents Inbred Lines and Their Six White Maize (Zea mays L.) Single Crosses Developed and Grown in Egypt. Journal of Applied Sciences Research, 3, 159-167.

[28] Shahidul, I., Haque, M.M., Bhuiyan, S.R. and Hossain, S. (2015) Path Coefficient Analysis and Correlation Coefficient Effects of Different Characters on Yield of Brassica rapa L. Plant, 4, 51-55. https://doi.org/10.11648/j.plant.20160406.12

[29] Uddin, M.S., Ahmed, A., Hossain, M.G., Karim, A.N.M.S., Talukder, M.Z.A., Almas, T., Ahmed, S. and Amiruzzaman, M. (2015) Selection Criteria, Evaluation and Associated Genomic Regions for Multiple Stress Tolerance (Salinity, Water Logged, Low-P) in Maize. Annual Report Maize and Barley Improvement, Plant Breeding Division, Bangladesh Agricultural Research Institute (BARI), Gazipur-1701, Bangladesh, 220-221.

[30] Kumar, V., Singh, S.K., Bhati, P.K., Sharma, A., Sharma, S.K. and Mahajan, V. (2015) Correlation, Path Coefficient Analysis in Maize (Zea mays L.). Environment \& Ecology, 33, 971-975.

[31] Pavan, R., Lohithaswa, H.C., Gangashetty, P. and Shekara, B.G. (2011) Correlation, Path Coefficient Analysis of Grain Yield and Yield Contributing Traits in Single Cross Hybrids of Maize (Zea mays L.). Electronic Journal of Plant Breeding, 2, 253-257. 